\title{
Development of Six KKNI Based Tasks Through Blended Learning Implementation on Oral Language Skills in English Education Unimed
}

\author{
Yeni Erlita \\ English Education Program Department, FBS, \\ Universitas Negeri Medan \\ Medan, Indonesia \\ yenierlita12@gmail.com
}

\author{
Nora Ronita Dewi \\ English Education Program Department, FBS, \\ Universitas Negeri Medan \\ Medan, Indonesia \\ noraronita@gmail.com \\ Anggraini Thesisia Saragih \\ English Education Program Department, FBS, \\ Universitas Negeri Medan \\ Medan, Indonesia \\ anggrainithere@gmail.com
}

\begin{abstract}
This research is aimed at developing sixtasks of KKNI Based Curriculum through implementing Blended Learning to Oral Language Skills study in English Education Study Program at Unimed. The objectives of this research are to identify the implementation of six tasks of KKNI based curriculum is appropriately standard to the students at the first semester of English Education Study Program, to design and develop the appropriate six tasks of KKNI based curriculum of Oral Language Skills through Blended Learning. Research and Development design applied in this research and skills covered in oral language are both listening and speaking. The results show that the six tasks used in the first semester of students are appropriately standard after having their answers toward the questionnaires of needs analysis given. The tasks indicated mid high level based on each part for those are designed through blended learning in a brandnewtemplate of e learning mode. The six tasks of KKNI Based Curriculum, namely Routine Task, Critical Book Review, Critical Journal Review, Engineering Idea, Mini Research, and Project are obviously developed to the needs of students in a revised KKNI based curriculum of Industrial Revolution 4.0 which characterized by the ability of students in creating products to support the demand of future revolution to achieve the learning outcomes of Oral Language Skills subject.
\end{abstract}

Keywords: Six tasks of KKNI Based Curriculum, Blended Learning, Oral Language Skills.

\section{INTRODUCTION}

Entering the industrial revolution era 4.0 where information technology has become the basis for human life. Everything becomes borderless with unlimited computing and data usage, because it is influenced by the development of the internet and massive digital technology as the backbone of human and machine movement and connectivity. This era will also disrupt various human activities, including the fields of science and technology (IPTEK) and higher education. The crucial problem that is often faced by lecturers is that there are still quite a lot of lecturers, especially in Language Skills teaching that have not used this standard KKNI based teaching material perfectly. Actually, there are many factors that cause this problem both the factors that are in the lecturer itself and the factors that are outside the lecturer. Therefore, the researchers conclude that the teaching of Language Skills seems appropriate when related to the role of the lecturer in referring to the KKNI curriculum reference in conducting the learning process. The development of the Higher Education curriculum should be based on KKNI, because the regulation of education is standardized through the following concept is based on the KKNI curriculum:

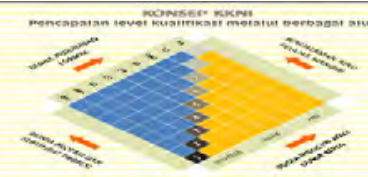

Fig 1. Concept of KKNI-based curriculum

In developing the assessment tool by referring to the PBM process in the curriculum which involves six tasks namely 1 . Routine Tasks (TR) 2. Critical Journal Reviews (CJR) 3. Critical Book Reports (CBR) 4. Engineering Ideas (Engineering Ide), 5.Mini Research (MR) and 6.Project (P) in the teaching of Oral Language Skills. English competence as a basic skill that every graduate of higher education must possess in facing global competition.In addition to the low competency of student language skills, the problem becomes increasingly serious because the language skills courses in the English Language Education Study Program of Medan State University have also not experienced significant review and development. In fact, learning outcomes of language skills at each level of teaching have not been described in the form of measurable statement formulations based on the results of the needs assessment. Each teacher uses his own teaching materials so that the competencies produced vary widely. This 
directly results in the problem of standardization of English language graduates both internally in relation to quality standardization and externally in relation to the competencies expected by users. Course Oral Language Skills are integrated skills between listening and speaking. Both of these abilities result from the ability to accept and produce language. Oral language is a system where we use spoken words to express knowledge, ideas and feelings. Developing English Language Languages (ELLs), then, means developing skills and knowledge that provide the basis for their hearing, speaking and writing. We all communicate with each other in various ways throughout our lives. One of the most common ways is to talk to each other. Most people communicate with each other through talking without problems.Blended learning is a learning method that combines face-to-face meetings with online material in harmony. A combination of conventional learning where educators and students meet directly with online learning that can be accessed anytime and anywhere. The other forms of blended learning are virtual meetings between educators and students. Where between educators and students may be in two different places, but can give each other feedback, ask, or answer. Everything is done in real time.

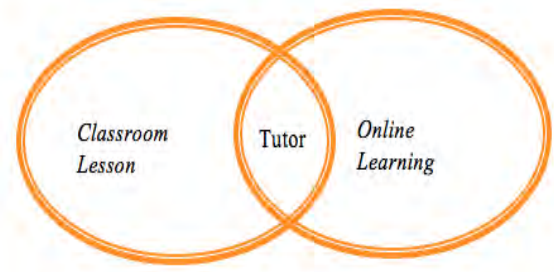

Fig. 2 Blended Learning, Sumber: Rusman,dkk(2012;242)

In addition, Carman, (2005) revealed that there are five keys to implementing learning using blended learning:

1. Live Event: Direct or face-to-face learning (instructorled instruction) synchronously in the same time and place (classroom) or the same time but a different place (virtual classroom). For some people, direct learning patterns like this are still the main patterns. However, even this direct learning pattern needs to be designed in such a way as to achieve the goals as needed. This pattern can also combine the theory of behaviorism, cognitivism and constructivism so that meaningful learning occurs.2. Self-Paced Learning: That is combining with self-paced learning that allows participants to learn anytime, anywhere by using various content (learning materials) specifically designed for independent learning both text-based and multimedia. based (video, animation, simulation, image, audio, or combination of all). The learning material, in the current context, can be delivered online (via the web or through mobile devices in the form of: audio streaming, video streaming, and e-books) and offline (on CD and print). 3 . Collaboration: Combining both educators and students, both of which can cross school / campus. Thus, blended learning designers must form forms of collaboration, either collaboration between peers or collaboration between students and educators through possible communication tools such as chatrooms, discussion forums, e-mail, website / weblog, and mobile phones. Of course collaboration is directed to the construction of knowledge and skills through social processes or social interaction with others, it can be for material deepening, problem solving and project-based learning. 4.Assessment: in a blended learning, the designer must be able to concoct a combination of types of assessment both in the form of tests and non-tests, or tests that are more authentic (authentic assessment/ portfolio). In addition, it is also necessary to consider ingredients between forms of online assessments and offline assessments. So as to provide convenience and flexibility for participants to learn to follow or do the research.5. Performance Support Materials: if we want to combine face-to-face learning in class and virtual faceto-face, pay attention to the resources to support it ready or not, there or not. Learning material is prepared in digital form, whether the learning material can be accessed by participants online.

The development of curriculum KKNI in universities, learning is more student-centered by focusing on the expected learning outcomes. The learning process prioritizes the development of creativity, capacity, personality, and needs of students, as well as developing independence in seeking and finding knowledge (Sailah et al., 2014). The development of blended learning models will encourage the acceleration of information and knowledge of students, so that it will improve effective learning. Effective learning can shape the learning process of active and productive students (Fry et al., 2009). Learning in college requires students to be active in developing material obtained from lecturers during face-to-face and outside lectures. Website-based blended learning development requires learning not only to focus on class hours, but learning will continue to run outside the classroom with website-based online media. The development of learning in the digital era, all activities and learning activities in universities involve electronic learning through a learning process that is not limited by time and space, so as to improve the quality of the learning process for students.

\section{METHOD}

Development of six task KKNI-based assessment tools for the teaching of Oral Language Skills in the English Language Study Program (English Language Education Department) Unimed using Research and Development design. This method is a research method used to produce products and test the effectiveness of these products (Sugiono, 2010). Research and development is a process or steps to develop a new product or perfect an existing product, which is accounted for (Trianto, 2008).

Development of the six-based tasks on Oral Language Skills in English Language Education Study Program have stages such as preliminary stage, development stage, and evaluation stage.

1. Preliminary stage

The preliminary stage is the stage of development research conducted to determine the analysis of problems and needs. This preliminary phase consists of an analysis of 
the needs of assessment tools. Six tasks for teaching the Language-based Skills of KKNI on English Language Education Program. Selection of types of assignments in Oral Language Skill teaching materials, standardization analysis of KKNI curriculum in English Study Program and analysis of teaching materials used.

2. Development phase

The development phase is the stage where information gathering and product development is carried out.

3. Evaluation Phase

The evaluation phase is a stage that aims to find out the development of six tasks based on KKNI through blended learning in the Oral Language Skill course. The evaluation phase consists of limited trials, questionnaires, questionnaire data analysis, the initial conclusions about the quality of the six tasks based on KKNI which are Routine Tasks (TR), Critical Book Review (CBR), Critical Journal Review (CJR), Mini Research (MR), Engineering Idea (RI), and Project (P). This data was analyzed using descriptive statistics. Each answer data question in the questionnaire is presented first with the following formula:

$$
\begin{aligned}
& \mathrm{P}=\mathrm{f} \times 100 \\
& \mathrm{n} \\
& \text { information: } \\
& \mathrm{P}=\text { percentage } \\
& \mathrm{f}=\text { number of answers } \\
& \mathrm{n}=\text { total answer }
\end{aligned}
$$

The data from the students' answers found from questionnaire 30 students from first semester in their necessities in Oral Language Skills course in completing six task KKNI based that the tasks are the students more interesting with blended learning and their competencies listening and speaking skill better.

\begin{tabular}{|c|c|c|c|}
\hline Six tasks & $\begin{array}{c}\text { Oral } \\
\text { Language } \\
\text { Skills }\end{array}$ & $\begin{array}{c}\text { Face } \\
\text { to } \\
\text { face }\end{array}$ & $\begin{array}{c}\text { Blended } \\
\text { Learning }\end{array}$ \\
\hline $\begin{array}{c}\text { 1.Routine } \\
\text { Task(TR) }\end{array}$ & Listening & High & High \\
\hline $\begin{array}{c}\text { 2. Critical } \\
\text { Book Review } \\
\text { (CBR) }\end{array}$ & Speaking & Mid & Mid \\
\hline $\begin{array}{c}\text { 3.Critical } \\
\text { Journal } \\
\text { Review } \\
\text { (CJR) }\end{array}$ & $\begin{array}{c}\text { Speaking } \\
\text { and } \\
\text { Listening }\end{array}$ & Mid & High \\
\hline $\begin{array}{c}\text { 4.Engineering } \\
\text { Idea (RI) }\end{array}$ & Speaking & Mid & High \\
\hline $\begin{array}{c}\text { 5.Mini } \\
\text { Research } \\
\text { (MR) }\end{array}$ & Listening & Mid & High \\
\hline 6.Project (P) & Listening & High & Mid \\
\hline
\end{tabular}

\section{DISCUSSION}

This finding provides information on appropriately that six tasks in KKNI-based can be used by lecturers and students to make it easier in completing six tasks in KKNI based on implementation on blended learning in English Education Program for first semester in Oral Language Skills course learning process in blended learning, especially for developing students in listening and speaking and improving learning achievement so that they can continue with better investigations related to this research.

In the development of blended-based learning used in one semester count is 5 months effective, then face to face is done in 2 to 3 weeks. The remaining 4 months 1 week students will study independently with web-based learning and semester exams. In the period of independent learning (4 months 1 week), students will gather and meet several times with the lecturer on the web or meet directly according to a predetermined schedule. The face-to-face process is intended to facilitate every problem faced by students during the learning process. Blended development also leads to the material used. The material used is in the form of material in electronic packaging. In blended learning, in addition to electronic module teaching materials, in the learning process students also utilize web-based material. The development of the six tasks of the KKNI implemented by other blended learning activities is the use of media or technology is one of the characteristics of the web-based learning process, including the use of text, audio, video, and multimedia is to enrich the sun to practice and to strengthen students in learning one of the topics. The learning method used is an independent learning method and collaborative learning method that uses information and communication technology facilities. The interaction strategy in developing blended learning has a basic variety of learning objects in each round of learning, designed and determined interaction patterns or learning strategies that can be taken by students. The students can practice themselves by accessing the new brand learning online anytime anywhere. The tasks indicated mid high level based on each part for those are designed through blended learning in a brand new template of e learning mode. The six tasks of KKNI based curriculum, namely Routine Task (TR), Critical Book Review (CBR), Critical Journal Review (CJR), Engineering Idea (RI), Mini Research (MR), and Project (P) are obviously developed to the needs of students in a revised KKNI based curriculum of Industrial Revolution 4.0 which characterized by the ability of students in acquiring their competencies in language skills. And the Oral Language Skill can be studied digitally and their competencies in language skills higher.

\section{CONCLUSION}

The implementation of six task KKNI in blended learning in Oral Language Skills that was developed contributed to the development of learning in the English Language Education of Medan State University and can be responded positively by students as users (there are $89.30 \%$ student ratings). Learning 
activities and the completion of six tasks both face-to-face and online show a good response. In addition, the implementation of developing blended learning using learning language skills in the form of presentation and web media, it should be done in a balanced manner between face to face, online and offline activities. Students are required to read the learning guide, by reading the learning guide students can understand the instructions for use and the expected competencies after the learning process is complete. So the learning process in using conventional and digital based are done in harmony and the first semester in English Education Program students' competences in language skills high in the progress of mastering English skills.

\section{REFERENCES}

[1] Harsono. 2005. Pengantar Problem-based Learning. Edisi kedua Medika-Fakultas Kedokteran Universitas Gadjah Mada.
[2] Hasan S. Hamid. 2014. Kerangka kualifikasi nasional Indonesia (kkni) dan pengembangan kurikulum S2 pendidikan IPA. https://adpgsdindonesia.files.wordpress.com.

[3] Murray Print, 1992. Curriculum development and design (second edition). Sidney: Allen \&Unwin.

[4] Nunan, David. 1999. Second Language Teaching \& Learning. Boston: Heinle \& Heinle.

[5] Peraturan Menteri Pendidikan dan Kebudayaan Republik Indonesia Nomor49 Tahun 2014 tentang Standar Nasional Pendidikan Tinggi.

[6] Richards, Jack C. and Rodgers, Theodore S. 2001. Approaches and Methods in Language Teaching.Second Edition. New York: Cambridge University Press.

[7] Sudjana, Dr. Nana. 2009. Penilaian Hasil Proses Belajar Mengajar. PT. Remaja Rosdakarya: Bandung

[9] Sani, Ridwan Abdullah. 2016. Penilaian Akademik Bumi Aksara: Jakarta.

[10] Tarigan, Henry Guntur. 1992. Dasar-Dasar Kurikulum Bahasa. Angkasa: Kurikulum.

[11] http://www.tugaspedia.com/20 tips-dan-trik-cara-mengerjakantugas.html

[12] https://www.kajianpustaka.com/2014/06/pengertian-karaktiristik-danmanfaat-elearning.html

[13] http://e-dufiesta.blogspot.co.id/2008/06/pengertian-e-learning.html 